\title{
Pengaruh Konsumsi Air Kelapa Terhadap Tekanan Darah Pada Pasien Hipertensi
}

\author{
Tarwoto, Mumpuni, Wahyu Widagdo \\ Dosen Jurusan Keperawatan Poltekkes Kemenkes Jakarta 1 \\ email : Tarwoto_spp@yahoo.com
}

\begin{abstract}
Abstrak
Pemberian suplemen tinggi kalsium dalam penanganan tekanan darah masih diperdebatkan dan belum jelas. Penelitian ini bertujuan untuk mengetahui apakah pemberian minuman alami tinggi kalsium berpengaruh terhadap tekanan darah pada pasien hipertensi. Desain penelitian ini adalah kuasi eksperimen dengan pre test post test one group desain. Responden pada penelitian ini adalah 30 orang lansia yang tinggal di Panti Werdha Budi Mulia 3 Margaguna Jakarta Selatan. Kriteria inklusi adalah semua lansia dengan hipertensi yang mendapat obat hipertensi. Pada minggu pertama selama 7 hari berturut-turut dilakukan pengukuran tekanan darahnya pada pagi hari. Selanjutnya pada minggu kedua responden yang sama setiap hari selama 7 hari diberikan minuman alami tinggi kalsium yaitu air kelapa muda hari sebanyak $3 \mathrm{x}$ $250 \mathrm{ml}$ yang diberikan pada pagi, siang dan sore hari. Selama intervensi lansia dengan hipertensi minum obatnya tetap dilakukan. Setiap hari responden diukur tekanan darahnya pada pagi hari. Hasil penelitian diperoleh adanya pengaruh yang bermakna pengaruh pemberian air kelapa muda terhadap tekanan darah systole dan diatole $(\mathrm{Pv}=$ $0,000, \alpha=0,05)$. Tidak terhadap hubungan antara IMT dan jenis kelamin dengan tekanan darah systole dan diatole pada pasien hipertensi. Tidak terdapat hubungan antara penyakit penyerta dengan tekanan darah sistole ( $\mathrm{Pv}$ systole $=0,086)$, namun terdapat hubungan antara penyakit penyerta dengan tekanan darah diastole $(\mathrm{Pv}$ diastole $=$ 0,027). Rekomendasi hasil penelitian ini adalah pemberian minuman alami tinggi kalsium (air kelapa muda) dapat diterapkan sebagai intervensi keperawatan untuk individu yang mengalami hipertensi.
\end{abstract}

Kata kunci : minuman alami tinggi kalsium, air kelapa muda, hipertensi

\footnotetext{
Abstract

The provision of high calcium supplements in handling blood pressure is still debated and unclear. This study aims to determine whether the provision of natural drinks high in calcium affects blood pressure in hypertensive patients. The design
}

of this research is quasi-experimental with pre-test post-test one group design. Respondents in this study were 30 elderly people living in Budi Mulia 3 Margaguna Panti Werdha South Jakarta. Inclusion criteria were all elderly with hypertension who received hypertension medication. During the first week for 7 consecutive days blood pressure measurements were taken in the morning. Furthermore, in the second week of the same respondent every day for 7 days, high calcium natural drinks were given, namely $3 \times 250 \mathrm{ml}$ of young coconut water given in the morning, afternoon and evening. As long as the intervention of the elderly with hypertension taking the medication is still done. Every day the respondent measured his blood pressure in the morning. The results of the study showed that there was a significant effect of the effect of giving young coconut water to systole and diatole blood pressure $(\mathrm{PV}=0,000, \alpha=0,05)$. No correlation between BMI and sex with systole and diatole blood pressure in hypertensive patients. There was no correlation between comorbidities and systolic blood pressure (systole $\mathrm{Pv}=0.086$ ), but there was a relationship between co-morbidities and diastolic blood pressure $(\mathrm{Pv}$ diastole $=0.027)$. The recommendation of the results of this study is the provision of high-calcium natural drinks (young coconut water) can be applied as nursing interventions for individuals who experience hypertension.

Keywords: natural high calcium drinks, young coconut water, hypertension

\section{Pendahuluan}

Tekanan darah merupakan faktor yang sangat penting pada sistem sirkulasi tubuh manusia. Peningkatan atau penurunan tekanan darahakan mempengaruhi homeostatsis di dalam tubuh. Tekanan darah selalu diperlukan untuk daya dorong mengalirnya darah di dalam arteri, arteriola, kapiler dan sistem vena, sehingga terbentuklah suatu aliran darah yang menetap.Jika sirkulasi darah menjadi tidak memadai lagi, maka terjadilah gangguan pada sistem transportasi oksigen, karbondioksida, 
dan hasil-hasil metabolisme lainnya. Di lain pihak fungsi organ-organ tubuh akan mengalami gangguan seperti gangguan pada proses pembentukan air seni di dalam ginjal ataupun pembentukan cairan cerebrospinalis dan lainnya. Salah satu masalah dalam gangguan tekanan darah adalah hipertensi. Hipertensi merupakan penyakit degenerative yang ditandai oleh peningkatan tekanan darah systole lebih dari $140 \mathrm{mmHg}$ dan diastole lebih dari $90 \mathrm{mmHg}$. Penyakit hipertensi merupakan pembunuh tersembunyi nomor satu karena hipertensi dapat menyebabkan penyakit jantung coroner, stroke, gagal ginjal dan lainnya.

Berdasarkan Badan Kesehatan Dunia WHO tahun 2011 ada satu milyar orang di dunia menderita hipertensi dan dua per-tiga diantaranya berada di negara berkembang yang berpenghasilan rendah-sedang. Angka kejadian hipertensi di Indonesia pada menurut Riskesdas tahun 2013 sebesar 25,8 \%, dan diprediksi akan meningkat setiap tahun meningkat sesuai dengan peningkatan usia harapan hidup dan perubahan pola hidup penduduk Indonesia. ${ }^{13}$

Masalah yang dihadapi berkaitan dengan meningkatnya jumlah usia lanjut adalah semakin meningkatnya angka kejadian hipertensi. Menurut Riskesdas 2013 angka kejadian hipertensi pada usia di atas 55 tahun sekitar 25,8 \%. Bahkan pada usia lanjut (lebih dari 65 tahun) menunjukkan satu dari dua orang menderita hipertensi. Peningkatan angka hipertensi pada lansia terjadi karena adanya perubahan vaskuler yaitu adanya arteriosclerosis, disamping factor lain seperti tidak adekuat meliputi mediator hormon, latihan vaskuler, volume sirkulasidarah, kaliber vaskuler, viskositas darah, curah jantung, elastisitas pembuluh darah dan stimulasi neural. Ada beberapa faktor yaitu faktor genetik, asupan garam dalam diet, tingkat stress dapat berinteraksi untuk memunculkan gejala hipertensi.
Peningkatan tekanan darah yang berlangsung dalam jangka waktu lama (persisten) dapat menimbulkan kerusakan pada ginjal (gagal ginjal), jantung (penyakit jantung koroner) dan otak (menyebabkan stroke) bila tidak dideteksi secara dini dan mendapat pengobatan yang memadai. Banyak pasien hipertensi dengan tekanan darah tidak terkontrol dan jumlahnya terus meningkat. Oleh karena itu diperlukan penanganan yang memadai khususnya oleh diri sendiri untuk mengontrol dan menstabilkan tekanan darah. Beberapa penelitian menunjukkan bahwa meningkatkan asupan kalsium dapat membantu seseorang untuk menurunkan tekanan darah. ${ }^{1}$ Namun sayangnya pemberian suplemen kalsium pada sebagai orang dirasakan mahal dan sulit didapat, oleh karenanya diperlukan alternative lain yaitu makanan/minuman tinggi kalsium yang mudah didapat serta murah harganya sehingga dengan mudah pasien hipertensi dapat menurunkan tekanan darahnya. Salah satu makanan atau minuman yang tinggi kalsum yang murah dan mudah didapat adalah air kelapa muda. Berdasarkan hasil penelitian Palungkun tahun 1992 air kelapa muda mengandung banyak kalsium yaitu sekitar 15 mg/100 gr air. Komponen lain dalam 100 gr air kelapa adalah protein 0.20 gr, lemak $1.00 \mathrm{~g}$, karbohidrat 3,80 gr, fospor 8.00, besi $0.20{ }^{10}$

\section{Metodologi Penelitian}

Desain penelitian ini adalah kuasi eksperimen dengan sampel pada lansia yang mengalami hipertensi yang minum obat antihipertensi di Pandi Werdha Budi Mulia 3 Jakarta dengan sampel 30 orang. Pada minggu pertama responden tidak dilakukan intervensi dan diukur tekanan darahnya setiap hari. Pada minggu ke dua responden diberikan minuman air kelapa muda setiap hari sebanyak 3 x 250 ml yaitu pada pagi, siang dan sore hari dan diukur tekanan darahnya. Obat-obatan antihipertensi pada responden tetap diminum selama intervensi.

\section{Hasil Penelitian}


1. Gambaran karakteristik responden

Tabel.1 Distribusi Responden Berdasarkan Jenis Kelamin dan Penyakit Penyerta

\begin{tabular}{llrc}
\hline \multirow{2}{*}{ Karakteristik Respondan } & & Frekuensi & \multirow{2}{*}{ Persen $(\%)$} \\
\cline { 2 - 4 } Jenis Kelamin & Laki-laki & 12 & 40 \\
\multirow{2}{*}{ Penyakit Penyerta } & Perempuan & 18 & 60 \\
& Tidak ada & 26 & 86,7 \\
& Ada & 4 & 13,3 \\
\hline Jumlah & & 30 & 100 \\
\hline
\end{tabular}

Tabel 2 Distribusi Responden Berdasarkan IMT pada kelompok Pre dan Post Test

\begin{tabular}{lcccc}
\hline Variabel & Mean & SD & Min -Max & $95 \%$ CI \\
\hline IMT & 21,34 & 5,13 & $14-34$ & $19,42-23,26$ \\
\hline
\end{tabular}

2. Gambaran rata-rata tekanan darah sistole dan diastole pada pre test dan post-test

Tabel 3 Hasil analisis rata-rata tekanan darah sistole dan diastole pada kelompok pre test dan post test

\begin{tabular}{llcccc}
\hline Tekanan Darah & & Mean & SD & Min-Maks & 95\% CI \\
\hline Sistole & Pre test & 144,24 & 11,72 & $126-174$ & $139,89-148,61$ \\
& Post test & 130,67 & 9,76 & $113-154$ & $130,67-134,31$ \\
& Selisih mean & 13,57 & & & \\
Diastole & Pre test & 86,43 & 4,26 & $79-96$ & $84,84-88,02$ \\
& Post test & 83,52 & 4,31 & $77-94$ & $81,95-85,13$ \\
& Selisih mean & 2,91 & & &
\end{tabular}

3. Pengaruh pemberian air kelapa muda terhadap tekanan darah sistole dan diastole pada pre dan post perlakuan.

Tabel 4 Hasil Analisis Rata-Rata Tekanan Darah Sistole dan Diastole pada pre dan post perlakuan

\begin{tabular}{ccccccc}
\hline & \multicolumn{5}{c}{ Tekanan Darah Sistole dan Diastole } \\
\hline Tekanan Darah & Kelompok & N & Mean & SD & SE & P value \\
\hline Sistole & Pre test & 30 & 144,24 & 11,72 & 2,139 & $0,000^{*}$ \\
& Post test & 30 & 130,67 & 9,76 & 1,782 & \\
& Selisih & & $-13,57$ & & & \\
Diastole & & 30 & 86,43 & 4,26 & 0,777 & $0,000^{*}$ \\
& & 30 & 83,52 & 3,31 & 0,786 & \\
& Selisih & & $-2,91$ & & & \\
& & & & & & \\
\hline
\end{tabular}

4. Pengaruh Jenis Kelamin terhadap tekanan darah pada pre dan post perlakuan 
Tabel 5 Hasil Analisis pengaruh jenis kelamin terhadap tekanan darah sistole dan diastole rata-rata pada pre dan post perlakuan

\begin{tabular}{lcccccc}
\hline Tekanan Darah & Jenis Kelamin & N & Mean & SD & SE & P value \\
\hline Sistole & Pre test & & & & & \\
& $\quad$ Laki-laki & 12 & 141,55 & 8,62 & 2,490 & 0,313 \\
& $\quad$ Perempuan & 18 & 146,03 & 13,33 & 3,141 & \\
& Post test & & & & & \\
& $\quad$ Laki-laki & 12 & 128,33 & 9,07 & 2,62 & 0,293 \\
Diastole & $\quad$ Perempuan & 18 & 132,22 & 10,14 & 2,39 & \\
& Pre test & & & & & \\
& $\quad$ Laki-laki & 12 & 85,48 & 4,94 & 1,43 & 0,326 \\
& $\quad$ Perempuan & 18 & 87,06 & 3,75 & 0,88 & \\
& & & & & & \\
& Post test & & & & & \\
$\quad$ Laki-laki & 12 & 82,74 & 4,28 & 1,24 & 0,424 \\
& Perempuan & 18 & 84,05 & 4,36 & 1,03 & \\
& & & & & \\
\hline
\end{tabular}

5. Pengaruh Penyakit Penyerta terhadap tekanan darah pada pre dan post perlakuan

Tabel 6 Hasil Analisis pengaruh Penyakit Penyerta terhadap tekanan darah sistole dan diastole rata-rata pada pre dan post perlakuan

\begin{tabular}{llccccc}
\hline Tekanan Darah & Penyakit Penyerta & N & Mean & SD & SE & P value \\
\hline Sistole & Pre test & & & & & \\
& $\quad$ Tidak ada & 26 & 145,82 & 11,66 & 2,29 & 0,057 \\
& $\quad$ Ada & 4 & 133,93 & 5,52 & 2,76 & \\
& Post test & & & & & \\
$\quad$ Tidak ada & 26 & 131,87 & 9,59 & 1,88 & 0,086 \\
& $\quad$ Ada & 4 & 122,86 & 7,82 & 3,91 & \\
Diastole & Pre test & & & & & \\
& $\quad$ Tidak ada & 26 & 86,81 & 4,41 & 0,86 & 0,213 \\
& $\quad$ Ada & 4 & 83,93 & 1,80 & 0,89 & \\
& Post test & & & & & \\
$\quad$ Tidak ada & 26 & 83,90 & 4,32 & 0,85 & 0,227 \\
& Ada & 4 & 81,07 & 3,76 & 1,88 & \\
& & & & & &
\end{tabular}

6. Pengaruh IMT terhadap Tekanan darah 
Tabel 7 Hasil Analisis Rata-Rata Tekanan darah Sistole dan Diastole berdasarkan IMT Pada Pre dan Post perlakuan

\begin{tabular}{llccccc}
\hline Tekanan Darah & IMT & $\mathrm{N}$ & Mean & $\mathrm{R}$ & $\mathrm{R}^{2}$ & $\mathrm{P}$ value \\
\hline Sistole & Pre test & 30 & 144,24 & 0,412 & 0,170 & 0,024 \\
& Post tes & 30 & 130,67 & 0,263 & 0,069 & 0,160 \\
Diastole & Pre test & 30 & 86,43 & 0,261 & 0,068 & 0,163 \\
& Post tes & 30 & 83,52 & 0,310 & 0,096 & 0,095 \\
\hline
\end{tabular}

\section{Pembahasan}

Tekanan darah merupakan tekanan yang berada dalam pembuluh darah, hal ini disebabkan karena kerja jantung sebagai pemompa. Hasil penelitian menunjukkan adanya penurunan tekanan darah diatole setelah dilakukan perlakuan. Perubahan tekanan darah sistolik dan diatolik diduga disebabkan karena peningkatan asupan kalsium melalui pemberian air kelapa muda. Kalsium sangat berperan dalam keseimbangan kalium dan natrium, karena bersifat natriuretic artinya peningkatan kalsium akan meningkatkan ekresi natrium dalam urin sehingga volume vaskuler menurun yang berakibat pada penurunan tekanan darah. Sehingga dapat disimpulkan adanya pengaruh yang signifikan konsumsi minuman alami tinggi kalsium terhadap tekanan darah systole dan diastole pada pasien hipertensi.

Air kelapa muda merupakan minuman alami yang tinggi kalsium, disamping ada unsurunsur lain seperti kalium, magnesium dan natrium. Kadar kalsium dalam air kelapa ratarata sebesar $15 \mathrm{mg} / 100 \mathrm{ml}$. Dengan pemberian 250 cc x 3 kali maka rata-rata konsumsi kalsium tambahan dalam satu hari sebanyak $37,5 \mathrm{mg}$. Pengaruh konsumsi kalsium ini dapat dijelaskan bahwa kalsium memiliki menstabilkan membran, efek vasorelaxing pada sel-sel otot polos. Hal ini juga mempengaruhi sistem saraf pusat dan perifer simpatik dan memodifikasi homeostasis kalsium, tindakan vaskular, serta tindakan elevasi diinduksi PTH pada kalsium untuk pada gilirannya mengurangi tonus vaskular. Kalsium juga dapat memberi efek melalui interaksi dengan nutrisi lainnya. Peningkatan asupan kalsium menyebabkan natriuresis (ekskresi natrium jumlah abnormal dalam urin). Kalsium dapat memperbaiki penurunan natrium kalsium terionisasi diinduksi seperti yang akan terjadi dengan natrium diinduksi calciuria. Garam sensitif, individu renin rendah biasanya menunjukkan konsentrasi kalsium plasma terionisasi rendah, ekskresi kalsium meningkat kemih, dan konsentrasi peningkatan PTH dan calcitriol. Penelitian menunjukkan bahwa asupan kalsium yang memadai muncul untuk melindungi terhadap efek hipertensi dari tinggi - diet natrium, kalium yang rendah.

Teori-teori yang berkaitan dengan mekanisme pengaruh kalsium terhadap tekanan darah masih belum jelas dan masih belum ada kepastian serta masih belum terbarukan. Para ahli masih sangat berbeda dalam menanggapi pengaruh supplement kalsium dalam penurunan tekanan darah. Sampai saat ini ada dua pendapat yang berbeda terkait peningkatan kalsium dalam tubuh. Pendapat pertama bahwa peningkatan kalsium akan meningkatkan tekanan darah seperti yang disampaikan oleh Christina dan Martinez. ${ }^{4}$ kekurangan makanan atau metabolisme kalsium dapat mengakibatkan kadar kalsium serum yang rendah. Keadaan ini mengakibatkan peningkatan hormone yang mengatur kalsium seperti paratiroid dan calsitrol. Hormon-hormon ini menyebabkan penurunan kandungan mineral kalsium dalam tulang dan meningkat kalium intraseluler terutama pada pembuluh darah otot polos. Peningkatan $[\mathrm{Ca} 2+]$ menghasilkan kontraksi dan karena vasokonstriksi sehingga tekanan darah akan meningkat. Pendapat yang kedua adalah penaingkatan kalsium dapat menurunkan tekanan darah seperti yang dikemukakan oleh Bande and Huballi menyatakan bahwa kadar kalsium yang tinggi sangat berkorelasi terhadap penurunan tekanan darah. $^{3}$ 
Studi yang dilakukan oleh Cormick tahun 2015 menyampaikan analisis hasil 16 kali percobaan dengan sampel 3048 menyimpulkan bahwa bahwa peningkatan asupan kalsium sedikit mengurangi tekanan darah sistolik dan diastolik masing-masing $1,43 \mathrm{mmHg}$ lebih rendah dan $0,98 \mathrm{mmHg}$ lebih rendah. Efek ini lebih tinggi dengan dosis kalsium di atas 1000 mg / hari. Tekanan darah sistolik berkurang 1,14 mmHg dengan dosis kalsium 1000 hingga $1500 \mathrm{mg} /$ hari dan $2,79 \mathrm{mmHg}$ dengan dosis kalsium sama dengan atau lebih dari $1500 \mathrm{mg}$ / hari. $^{5}$

a. Pengaruh jenis kelamin dengan tekanan darah

Hasil penelitian menunjukkan tidak ada pengaruh jenis kelamin pada tekanan darah setelah pemberian air kelapa muda. $\mathrm{p}=0,293$ ( $p>0,05)$. Hasil penelitian ini didukung oleh Anggara tahun 2013 penelitian sebelumnya yang menyatakan tidak ada hubungan antara jenis kelamin terhadap tekanan darah. ${ }^{2}$ Penelitian lain yang dilakukan oleh TriNovitaningtyas tahun 2015 pada lansia, diperoleh hasil yang sama bahwa jenis kelamin tidak berpengaruh terhadap tekanan darah. ${ }^{12}$

b. Pengaruh penyakit penyerta terhadap tekanan darah

Hasil penelitian ini menunjukkan penyakit penyerta pada sebelum perlakuan ada perbedaan mean tekanan darah systole sebesar 11,89 $\mathrm{mmHg}$ dan setelah perlakuan selisih mean 9,01 mmHg. Hasil uji statistic pada sebelum perlakuan menunjukkan nilai $\mathrm{p}=0,057$ dan setelah perlakuan $\mathrm{p}=0,086$ sehingga dapat disimpulkan tidak adanya pengaruh yang signifikan tekanan darah systole dengan penyakit penyerta.

Pada tekanan darah diastole, hasil penelitian menunjukkan sebelum perlakuan nilai $\mathrm{p}=0,213$ dan sesudah perlakuan nilai $\mathrm{p}=0,027$, sehingga dapat disimpulkan tidak adanya pengaruh penyakit penyerta terhadap tekanan darah pada pasien hipertensi. Hasil penelitian ini mungkin disebabkan karena jumlah penyakit penyerta yang ada relative sedikit dibandingkan dengan yang tidak mempunyai penyakit sehingga hasilnya sangat berbeda dengan teori yang ada dimana penyakit-penyakit seperti diabetes militus, gagal ginjal, penyakit jantung dan hiperkolesterol berpengaruh terhadap tekanan darah.

\section{c. Pengaruh IMT terhadap tekanan darah}

Indeks Massa Tubuh (IMT) merupakan ukuran penilaian terhadap pemantauan status gizi pada orang dewasa yang berkaitan dengan kekurangan dan kelebihan berat badan. Hasil penelitian ini menunjukkan tekanan darah systole sebelum perlakuan nilai $\mathrm{p}=0,024$ artinya ada hubungan IMT terhadap tekanan darah systole sebelum perlakuan, dengan nilai $\mathrm{R}$ $=0,412$ menunjukkan adanya hubungan yang sedang dan berpola positif, artinya semakin tinggi IMT semakin tinggi tekanan darah sistolenya. Hasil penelitian ini sesuai dengan hasil penelitian yang dilakukan oleh Sumayku tahun 2014, yang menunjukkan bahwa indeks massa tubuh berlebih mempunyai hubungan dengan tekanan darah dengan nilai $\mathrm{p}=0,001$ dan 0,004 $(\mathrm{p}<0,01)$ dengan korelasi koefisien adalah 0,286 dan 0,252. ${ }^{11}$ Demikian juga penelitian yang dilakukan oleh Effendi pada tahun 2008 didapatkan ada hubungan yang bermakna $(\mathrm{p}=0,038)$ antara indeks massa tubuh dengan tekanan darah sistolik sebanyak 0,362 mmHg. $^{6}$

Pada post perlakuan pengaruh MIT terhadap tekanan darah systole diperoleh nilai $\mathrm{p}=0,16$, pada tekanan diastole sebelum perlakuan nilai $\mathrm{p}=0,163$ dan setelah perlakuan nilai $\mathrm{p}=0,095$, sehingga dapat disimpulkan tidak ada pengaruh IMT terhadap tekanan darah sistoleh setelah perlakuan dan tidak ada pengaruh IMT terhadap tekanan darah diastole. Hasil penelitian ini berbeda dengan penelitian terdahulu yang dilakukan oleh Nieky Greyti Dien tahun 2014, hubungan antara indeks massa tubuh dengan tekanan darah sistolik $\mathrm{p}=0,009(\mathrm{p}<0,05)$ dan indeks massa tubuh dengan tekanan darah diastolik $\mathrm{p}=0,001$ $(\mathrm{p}<0,05){ }^{9}$ Hasil uji korelasi Spearman menunjukkan ada hubungan indeks massa tubuh dengan tekanan darah pada penderita hipertensi. Penelitian lain yang dilakukan oleh Lathiifahayyu tahun 2014, juga menunjukkan perbedaan tekanan darah dengan indeks massa tubuh normal dan 
overweight pada pasien hipertensi baik tekanan darah systole maupun diastol $(\mathrm{p}<0,05){ }^{8}$

Hubungan anatara IMT dengan tekanan darah dapat dijelaskan bahwa pasien yang mengalami peningkatan IMT atau obesitas maka kecenderungan terjadi peningkatan kolesterol LDL dan penurunan kolesterol HDL. Kolesterole LDL bersifat arteriogenik dan merusak arteri sehingga meningkatkan tahan perifer yang pada akhirnya terjadi peningkatan tekanan darah. $^{7}$

\section{Kesimpulan}

Terdapat pengaruh yang bermakna pemberian minuman alami tinggi kalsium (air kelapa muda) terhadap tekanan darah systole dan diastole $(\mathrm{p}=0,000)$. Tidak ada pengaruh antara jenis kelamin, IMT dan penyakit penyerta dengan tekanan darah systole dan diastole.

\section{Saran}

Selama ini masih ada kontroversi peranan kalsium dalam penurunan tekanan darah. Penelitian ini membuktikan bahwa minuman alami tinggi kalsium berpengaruh secara signifikan dalam penurunan tekanan darah systole dan diatole pada pasien hipertensi, sehingga perlu dilakukan sosialisasi atau penyuluhan kesehatan tentang manfaat air kelapa muda dalam pengendalian hipertensi

\section{Daftar Pustaka}

1. Alfiana N, Bintanah, Kusuma.S, Hubungan Asupan Kalsium dan Natrium Terhadap Tekanan Darah Sistolik Pada Penderita Hipertensi Rawat Inap Di RS Tugurejo Semarang, Jurnal Gizi Universitas Muhammadiyah Semarang, 2014.

2. Anggara F,H,D, Prayitno N, Faktor Yang Berhubungan Dengan Tekanan Darah Di Puskesmas Telaga Murni, Cikarang Barat Tahun 2012, Jurnal Ilmiah Kesehatan, 5(1); Jan 2013.

3. Bande and Huballi , Study Of Serum Calcium In Essential Hypertension, ejpmr, 2016,3(6), 516-525.

4. Christina and Martinez, Calcium and Hypertension, Nutrition Bytes, University of California, Los Angeles, 1998.

5. Cormick G, Ciapponi A, Cafferata M, Belizán JM, Extra calcium to prevent high blood pressure, Cochrane, 2015.

6. Effendi I, Hubungan Indeks Massa Tubuh, Jenis Kelamin, Usia, Golongan Darah dan Riwayat Keturunan dengan Tekanan Darah pada Pegawai Negeri Sipil di Pekan Baru, 2008
7. Kumar V, Cotran RS, Robbins SL, Buku ajar patologi, 7nd ed, Vol. 1. Jakarta : Penerbit Buku Kedokteran EGC, 2007

8. Lathiifahayyu, L, Perbedaan Tekanan Darah Dengan Indeks Massa Tubuh Normal Dan Overweight Pada Pasien Hipertensi Di Rumah Sakit Umum Daerah Karanganyar, Skrpsi, Fakultas Kedokteran Universitas Muhammadiyah Surakarta, 2014.

9. Nieky Greyti Dien, Mulyadi, Kundre, Hubungan Indeks Massa Tubuh (Imt) Dengan Tekanan Darah Pada Penderita Hipertensi Di Poliklinik Hipertensi Dan Nefrologi Blu Rsup Prof. Dr. R. D. Kandou Manado, Tesis,Program Studi Ilmu Keperawatan Fakultas Kedokteran Universitas Sam Ratulangi Manado, 2014.

10. Palungkun, Rony. Aneka Produk Tanaman Kelapa. Penebar Swadaya. Jakarta. 1992, 118 Hal.

11. Sumayku I, M. Hubungan Indeks Massa Tubuh dan Lingkar Pinggang dengan Tekanan Darah pada Mahasiswa Fakultas Kedokteran Universitas Sam Ratulangi. ejournal.unsrat, 2014.

12. Tri Novitaningtyas, Hubungan Karakteristik (Umur, Jenis Kelamin, Tingkat Pendidikan) Dan Aktivitas Fisik Dengan Tekanan Darah Pada Lansia Di Kelurahan Makamhaji Kecamatan Kartasura Kabupaten Sukoharjo, Skripsi, Program Studi S1 Gizi Fakultas Ilmu Kesehatan Universitas Muhammadiyah Surakarta, 2014

13. World Health Organization. Data Hipertensi Global. Asia Tenggara: WHO, 2012. 
